\section{Crop Load, Fruit Thinning and their Effects on Fruit Quality of Apple (Malus domestica Borkh.)}

\author{
József Racskó \\ University of Debrecen, Centre for Agricultural Sciences, \\ Institute for Extension and Development, Debrecen \\ racsko@agr.unideb.hu
}

\section{SUMMARY}

Crop load, a quantitative parameter used by industry, is generally defined as the number of fruit per tree. It is often expressed in terms of number of fruit per trunk cross-sectional area (fruit/TCSA). Crop load is the most important of all factors that influence fruit size, and the removing of a part of the crop is the most effective way to improve fruit size.

The potential size of a given pome fruit is determined early in the season and growth proceeds at a relatively uniform rate thereafter. This uniform growth rate permits the accurate prediction of the harvest size of the fruit as early as mid-summer. The growth rate, once established, is not easily altered, and fruit numbers, therefore, can affect fruit size only within definite limits and maximum effectiveness requires adjustment in fruit numbers relatively early in the season. It was established, that „thinning does not change a potentially small fruit into a large fruit, but rather insures that a potentially large fruit will size properly." Emphasis should be on estimating fruit numbers rather than fruit size.

Fruit thinning can quickly reach the point of diminishing returns. Rather than a high percentage of large fruits, the objectives of thinning should be the elimination of the smallest fruits, improved fruit quality and annual production. Fruit thinning is accomplished by hand or chemical thinning. Chemical thinners are separated into categories as bloom thinners and postbloom thinners. Early removal of potential fruit (blossom thinning) is currently used in many apple producing areas to enhance flower initiation for next year's crop and thus, return bloom. It also results in reduced competition for photosynthates. Blossom thinners usually have a caustic effect on floral parts.

The amount of fruit left on a tree should be determined by the vigor and general condition of the tree. Leaf area per fruit affects the number of spurs flowering the following season. It can be difficult to separate timing and fruit number effects in crop loading studies, as abscission rates after hand thinning of retained flowers/fruitlets tend to very with the time of hand thinning.

Keywords: apple (Malus domestica Borkh.), crop load, fruit thinning, fruit quality

\section{INTRODUCTION}

Crop load, a quantitative parameter used by industry, is generally defined as the number of fruit per tree. It is often expressed in terms of number of fruit per trunk cross-sectional area (fruit/TCSA). Jones et al. (1992) described crop load as the number of fruit per 100 blossom clusters. Crop load on a tree has been described as light (125 fruit/tree) or normal (300 fruit/tree) on M.26 rootstock by Francesconi et al. (1996). Crop load was expressed later in this study in terms of fruit/TCSA because of some variation in tree size.
Crop load has been studied for individual cultivars. A mean fruit weight of 150 grams for 'Golden Delicious' was achieved by thinning to 3050 fruit per 100 blossom clusters (Williams and Edgerton, 1981; Jones et al., 1984; Koen and Jones, 1985); this corresponds to $1.5-2.0$ fruit per $\mathrm{cm}^{2}$ trunk area (fruit/TCSA) (Jones and Koen, 1986; Jones et al., 1988b). Targets for 'Red Delicious' have been similar but slightly higher at 40-60 fruit per 100 blossom clusters and 2 to 4 fruit per $\mathrm{cm}^{2}$ trunk area (TCSA) (Koen et al., 1988; Jones et al., 1988a). Crop load is the most important of all factors that influence fruit size, and the removing of a part of the crop is the most effective way to improve fruit size (Forshey, 1976). In a normal year, a tree setting $10 \%$ of its blossoms will have a full crop load (Williams and Edgerton, 1981). Overcropping results in a very poor fruit weight and size (Jones et al., 1992). Overcropping could have more farreaching effects than poor performance at harvest. Stebbins (1989) showed that overcropping (7-13 fruit per $\mathrm{cm}^{2}$ crosssectional area) in 10 apple cultivars led to a poor crop the next year.

Apple fruit size has always been a critical factor in determining market value. Early removal of fruit results in larger fruit size at harvest (Preston and Quinlan, 1968; Quinlan and Preston, 1968; Jones et al., 1992). The potential size of a given pome fruit is determined early in the season and growth proceeds at a relatively uniform rate thereafter (Forshey and Elfving, 1977).

Batjer (1965) suggested that the increase in fruit size was roughly proportional to the degree of thinning. However, studies have shown the increase in fruit size was proportionately less than the reduction in fruit set (Batjer and Thomson, 1961; Rogers and Thompson, 1969) or in the number of fruits/tree (Southwick and Weeks, 1949; Way, 1965). The close relationship between fruit numbers and yield regardless of tree size, clearly indicates that this is the dominant factor contributing towards economic yield. A negative correlation between fruit size and fruit numbers exists because the major objective of fruit thinning is an increase in fruit size (Forshey and Elfving, 1977).

Previous results with many cultivars (Batjer and Thomson, 1961; Batjer and Westwood, 1960; Rogers and Thompson, 1969; Southwick and Weeks, 1949; Way, 1965) demonstrated that increases in fruit size were proportionately less than the reduction in fruit numbers. The primary effect of fruit thinning on fruit size is more often a reduction in the number of smaller fruits than a dramatic increase in the size of 
the remaining fruits (Forshey and Elfving, 1977).

The potential size of a given pome fruit is determined early in the season and growth proceeds at a relatively uniform rate thereafter. This uniform growth rate permits the accurate prediction of the harvest size of the fruit as early as mid-summer (Batjer et al., 1957). The growth rate, once established, is not easily altered, and fruit numbers, therefore, can affect fruit size only within definite limits and maximum effectiveness requires adjustment in fruit numbers relatively early in the season (Forshey and Elfving, 1977). Tukey (1970) states, „thinning does not change a potentially small fruit into a large fruit, but rather insures that a potentially large fruit will size properly.” Emphasis should be on estimating fruit numbers rather than fruit size.

Fruit thinning can quickly reach the point of diminishing returns. Rather than a high percentage of large fruits, the objectives of thinning should be the elimination of the smallest fruits, improved fruit quality and annual production (Forshey and Elfving, 1977). Fruit thinning is accomplished by hand or chemical thinning. Chemical thinners are separated into categories as bloom thinners and post-bloom thinners. Early removal of potential fruit (blossom thinning) is currently used in many apple producing areas to enhance flower initiation for next year's crop and thus, return bloom (Fallahi, 1997a; Fallahi et al., 1997). It also results in reduced competition for photosynthates. Blossom thinners usually have a caustic effect on floral parts.

The practice of post-bloom thinning, which generally occurs at the $3-18 \mathrm{~mm}$ fruit size stage, is used to promote return bloom, as well as to regulate crop load. Fruit removal which occurs after the period of flower initiation (30 to 40 days after full bloom) will affect crop load only (Williams, 1999). For this reason, hand thinning is used to balance crop load and to improve fruit size, rather than influence flower initiation.

The use of napthalene acetic acid (NAA), a synthetic auxin gained acceptance in the 1950's and 1960's. Another synthetic auxin, napthaleneacetamide (NAD), was found to be suitable for post-bloom thinning of many commercial apple varieties (Westwood and Batjer, 1960). In the 1960's carbaryl (Sevin), a commonly used insecticide was introduced as a post-bloom thinner (Williams, 1994). In the 1970's combinations of carbaryl and NAA, or carbaryl and NAD, were adopted as commercially acceptable post- bloom thinning sprays. Also, in the 1970's most of the other plant bioregulators such as gibberellins, cytokinins, and ethylene were tested. In the 1980's, synthetic cytokinins such as 6-benzyladenine were used in chemical thinning experiments.

The mode of action of the post-bloom thinning chemicals is not entirely known. They are generally believed to interfere with the endogenous hormones that control the flow of nutrients to the developing fruit which leads to embryo abortion and fruit abscission (Williams and Edgerton, 1981).

\section{Factors that influence thinning response}

Tree vigor is a major factor in thinning response. The physiological or growth status of the tree affects results with thinning sprays (Williams and Edgerton, 1981). The influence of spur vigor was illustrated by a positive correlation between bud diameter and resistance to action of NAA (Southwick and Weeks, 1949).

Young trees are more easily thinned than older trees with established bearing habits. This response of young trees to thinning sprays is perhaps related to their more rapid vegetative growth and a consequent reduction in carbohydrate and other reserves available to the young, developing fruit in the early post-bloom period (Williams and Edgerton, 1981).

Cool, wet weather either before or after application will precondition the leaves and increase chemical absorption of all thinning agents. Absorption efficiency is influenced in part by the physiological status of the plant and particularly by the cuticle, which is considered a major barrier to absorption (Williams and Edgerton, 1981).

Environmental factors such as humidity, affect both thickness and composition of plant leaf cuticle (Lee and Priestly, 1924). Factors such as temperature and light further complicate post-bloom thinning. If cool, cloudy weather predominates during the fall, carbohydrate reserves may be reduced for the next spring (Byers et al., 1990). If temperatures are warm during bloom, carbohydrate reserves are used at a faster rate than if temeratures are cool. With fewer reserves available to both vegetative and fruit growth, fruit set and thus, yield may be reduced (Robinson et al., 1998; Williams and Edgerton, 1981).

Trees in low vigor are easy to thin or overthin, but adequate thinning of such trees does not necessarily result in good fruit size or in adequate repeat bloom. Low vigor is often due to inadequate nitrogen fertilizer (Forshey, 1976).

Light exposure also affects thinning responses. Heavily shaded wood, whether on lower branches that have been over-grown by the tops, or in the interior of dense, inadequately pruned trees, is easily over-thinned (Forshey, 1976).

An excessive crop reduces tree vigor the following season and at the same time increases susceptibility to thinning. Strongly biennial varieties are easier to thin in the „off” year (following a heavy crop) than in the „on” year (following a light crop) (Forshey, 1976).

Trees cropped heavily the previous year are more easily thinned. The amount of bloom on the tree affects the thinning response. Trees with heavy bloom are more susceptible to chemical treatments than trees with light bloom. Generally, when bloom is light, fruit set per spur is heavy, and the effect of chemical thinning reduced (Williams and Edgerton, 1981).

Prolonged soil moisture deficits can also affect tree vigor, fruit set, and the response to thinning the following year. Moisture stress of sufficient severity 
to induce wilting for 2-3 weeks will be reflected in increased effectiveness of thinning sprays (Forshey, 1976).

\section{Nutritional factors affecting cropping and tree growth}

Regular cropping can be influenced by the nutrition management of the orchard. This management has an effect on the cropping cycle of the trees. The nutritional elements that affect cropping consist of major and minor elements. The three major elements include nitrogen, phosphorus, and potassium. The minor elements include magnesium, boron, manganese, zinc, and copper. Nitrogen has both direct and indirect effects on the regularity of cropping. The direct effects include flower initiation (Tami et al., 1986) and development, length of the period of ovule receptivity, and fruit set (Williams, 1965). The indirect effects of nitrogen are those related to vigor of trees as indicated by shoot and spur growth, and leaf area to support photosynthesis and the production of carbohydrate reserves (Boynton and Anderson, 1956; Magness et al., 1948; Rogers and Thompson, 1962).

A deficiency of nitrogen (less than $1.5 \%$ in midsummer shoot leaves) may prevent flower bud formation (Stiles, 1999). High nitrogen levels (more than $2.4 \%$ ) can be associated with excessive vegetative growth and poor flower bud initiation in shaded interior portions of the trees (Stiles, 1999). Tami et al. (1986) found that leaf nitrogen levels were positively correlated with percent floral buds and with fruit yield in the second year of soil applications of urea to ten-year-old 'Starkspur Golden Delicious' trees. In the first year, fruit set was increased $11 \%$ by the urea treatment. Floral bud initiation during the second year of treatment was increased 7\%. Crop density (fruit per limb crosssectional area) was increased both years but not at statistically significant levels. Fallahi (1997b) observed lower yields of 'Red Spur Delicious' from trees that had recieved low annual nitrogen (45.3 g/tree) applications, but no significant differences in yields among trees that relieved nitrogen at 181.4 to $589.6 \mathrm{~g} /$ tree. Current recommendations for nitrogen management include an application of a prebloom urea spray when the previous season analysis shows leaf nitrogen values of less than $2.4 \%$ (Stiles and Reid, 1991).

Phosphorus applications to established orchards have not resulted in a significant increase in cropping. Neilson et al. (1990) found that application of monoammonium phosphate (MAP) in the year of planting increased leaf phosphorus levels, blossoming and fruit set in the next year on trees planted in non-replant soil. In field trials in eight replant orchards, only one orchard had increased yield by the end of the third growing season (Neilsen, 1994).

Potassium affects cropping indirectly through effects on tree vigor. In a fertigation study (Stiles,
1998) trees established in 1993 and deblossomed during the first two seasons showed a significant increase in shoot growth in response to potassium. Yields during the first three cropping seasons were related positively with shoot growth during the first two growing seasons. The lowest rate of potassium used in this trial, $33.2 \mathrm{lbs} . / \mathrm{A}$ (42 kg/ha) per year met requirements in terms of shoot growth, yield, and maintaining leaf potassium at the desired range of $1.35 \%$ to $1.80 \%$. Potassium requirement is directly related to crop load. It is expected for this level to increase as the tree matures (Stiles, 1998).

Magnesium has both direct and indirect effects. Magnesium deficiency results in reduced vigor of shoots and spurs tend to be thin, weak, and brittle (Boynton and Oberly, 1966). Flowering may be reduced if excessive leaf drop occurs early in the season. Fisher et al. (1958) reported increased yield over four years after correcting magnesium deficiency with applications of dolomitic limestone. Greenham and White (1959) showed that post bloom Epsom salts (MgSO4.7H20) sprays applied to magnesium deficient 'Edward VII'/Malling 7 trees over a five year period did not increase the number of fruit buds produced but did improve fruit set set by an average of $68 \%$. Crop production per tree increased significantly in two of the five years, and the total crop for the five year period was $80 \%$ greater with the Epsom salts sprays. Adequate magnesium levels occur between .35\% to .50\% and/or a potassium to magnesium ratio smaller than 4:1 in leaf samples collected 60 to 70 days after petal fall (Stiles and Reid, 1991).

Boron affects cropping in several ways. Boron deficiency has been shown to result in reduced flowering; abnormal development of flowers; reduced pollen tube development and germination; and severe reduction in fruit set. Severe boron deficiency results in death of meristematic tissues and poor development of conducting tissues (Stiles and Reid, 1991). Reports indicate beneficial effects of foliar applications of boron, either postharvest or before bloom, in increasing fruit set of apples. Davidson (1971) reported increases in fruit set of 6\% to $29 \%$ in 11 trials when boron sprays were applied at open cluster (pink) and again at $80 \%$ to $100 \%$ petal fall. Midsummer leaf sample contents of 35 to 50 ppm (mg.L-1) boron are considered to be adequate (Stiles and Reid, 1991). Woodbridge et al. (1971) found relatively high levels of boron in developing buds of apple, pear (Pyrus communis L.), and cherry (Prunus avium L.). They reported that both total boron per bud and concentration of boron on a dry weight basis gradually increased as buds enlarged and rapidly increased as the flowers opened to full bloom. The levels reached their maximum when pollination and fertilization occurred and the total boron decreased significantly at petal fall. Boron toxicity can cause abnormal flower development and reduced cropping. Hansen (1981) found excessive boron to result in delayed development of buds and bloom, reduced blossom density, and reduced yields. Mild deficiencies of manganese do not appear to 
influence cropping (Stiles, 1999). Maintaining a midsummer leaf content of at least 35 to $150 \mathrm{ppm}$ (mg.L-1) manganese should minimize the possibility of manganese deficiency (Stiles and Reid, 1991).

Flowering and cropping are reduced by zinc deficiency and may be eliminated under severe deficiency (Stiles and Reid, 1991). Zinc deficiency reduces growth and general tree vigor and if severe can result in die back of shoots or limbs. This effect is often not uniform throughout the tree but may be more severe on individual limbs than on others. There is always a reduction in the number of flower buds on severely effected trees (Chandler, 1937). Average yield of 'McIntosh' trees, over a three year period, was increased $30 \%$ by receiving annual midJune foliar sprays of EDTA-zinc chelate. A single application of EDTA-zinc at the pink stage increased yield of 'McIntosh' by $17 \%$ over a two year period (Stiles, 1980).

Neilson (1988) showed that mid-shoot leaf zinc levels declined from a high of 40 ppm (mg.L-1) in early May to values approaching or below $14 \mathrm{ppm}$ (mg.L-1) by midsummer. Thus, one of the difficulties in assessing zinc status is determining when to sample (Stiles, 1999). Copper deficient trees may exhibit poor shoot growth or die back of shoots, reduced bloom, and poor fruit set (Stiles and Reid, 1991). Copper levels in bud tissues may be fairly high at the beginning of growth, but the level in leaf tissues declines rapidly as growth proceeds (Stiles, 1999). Experiments suggest a midsummer leaf level of 7 to $12 \mathrm{ppm}$ (mg.L-1) to be optimal (Stiles and Reid, 1991).

\section{Biennial bearing/return bloom}

Seeds contain relatively high concentrations of gibberellic acids (Luckwill et al., 1969), and Luckwill (1970) proposed that gibberellic acids from the seeds diffuse to the bourse shoot, where they inhibit flowering. The most popular hypothesis to explain the effects of seeds on flowering is that seeds, being rich sources of hormones, export these compounds to the bourse bud, thus inhibiting flowering (Dennis and Neilson, 1999). Direct evidence for this mechanism has yet to be obtained. A second hypothesis, which appears to be just as feasible, is that seeds compete with other plant tissues for a compound (florigen), produced by the leaves, that promote flowering (Dennis and Neilson, 1999). This reduces the quantity available for flower induction. A possible candidate for this promoter is cytokinin. Hand thinning 'York'/M.26 trees at bloom by removal of $2 / 3$ of the flower clusters or by hand thinning weekly up to 61 days after bloom did not provide adequate return bloom for even a partial crop the next year (Byers, 1999). Trees with a moderate level of flowering were more likely to give an adequate return bloom than if trees had near $100 \%$ of the spurs flowering and thinned at bloom or shortly thereafter (Byers, 1999).

Trees usually bear on alternate years because fruit set is excessive during the „on year”. When the quantity of fruit on the tree in relation to the amount of foliage is excessive, fruit bud formation is reduced or entirely prevented. Thus, in the season following the „on year” the reduction in bloom results in a short crop; then under the conditions in the „off year”, too many fruit buds form. Once begun, such a fruiting pattern tends to become established (Williams and Edgerton, 1981).

Perhaps the most outstanding feature of chemical thinning sprays is their effect on alternate bearing. These sprays reduce fruit set relatively early in the growing season, and the tree forms more fruit buds for the next year's crop (Williams and Edgerton, 1981).

\section{Final Crop Load}

The amount of fruit left on a tree should be determined by the vigor and general condition of the tree. Leaf area per fruit affects the number of spurs flowering the following season (Harley and Moon, 1957; Williams and Edgerton, 1981). It can be difficult to separate timing and fruit number effects in crop loading studies, as abscission rates after hand thinning of retained flowers/fruitlets tend to very with the time of hand thinning (Palmer and Adams, 1996).

\section{Crop load effects on fruiting, fruit quality and vegetative growth}

Crop load affects fruit size of apples (Assaf et al., 1982; Erf and Proctor, 1987; Forshey and Elfving, 1989). A reduction in fruit numbers is associated with increased fruit growth. The primary effect of fruit thinning on fruit size is more often a reduction in the number of smaller fruits than a dramatic increase in the size of the remaining fruit (Forshey and Elfving, 1977). Reducing the number of fruits per tree will inevitably increase the leaf area per fruit, resulting in an increase in the availability of assimilates to the remaining fruitlets (Palmer et al., 1991).

Light-cropping apple trees tend to bear fruit that are more susceptible to storage disorders, such as bitter pit, than are fruit from medium to heavy cropping trees (Ferguson and Watkins, 1989). A heavy crop load being defined as $120-130 \mathrm{~kg}$ of fruit per tree, and a light crop load being defined as 80-90 $\mathrm{kg}$ of fruit per tree. Large fruit are more susceptible to bitter pit since they tend to have a lower calcium concentrations (Ferguson and Triggs, 1990). Although vegetative growth may be stimulated by crop removal, naturally light-cropping trees may have less shoot growth than heavy-cropping trees (Forshey and Elfving, 1989). Light cropping and thinned trees have less flower bud density and greater fruit set than the heavy-cropped trees (Voltz et al., 1993).

When fruit numbers or crop load are reduced by thinning, the leaf/fruit ratio is improved, but a portion of any resultant increase in the supply of metabolites is diverted into vegetative growth (Forshey and 
Elfving, 1977). When spurs with fruit of similar size at the end of the season were compared, those with lighter crop loads had greater primary and bourse leaf areas than those from heavier crop load treatments (Voltz et al., 1993). Fruit from heavily cropped trees has been shown to have higher calcium and magnesium content, and lower potassium content than fruit from light cropped trees. Fruit from light cropped treatments had a higher incidence of internal breakdown after storage (Voltz et al., 1993). Reducing crop load has been shown to increase fruit firmness at harvest. The greatest increase in fruit firmness at harvest was achieved by thinning during the period from five to fifteen days after full bloom with no increase when thinned at twenty-five days after full bloom for 'Cox's Orange Pippin' (Johnson, 1994). Increased crop load affects the dry-matter production of the tree. Increasing the fruit load on apple trees increased dry-matter production per leaf unit area and the amount of dry-matter partitioned into the crop (Palmer, 1992). It is important that the crop load be evenly distributed throughout the tree. Flower clusters were removed at full bloom from ten year old 'Cox's Orange Pippin' trees on M.9 rootstock, over the whole tree, on alternate branches or on a complete side of the canopy. Mean fruit weight per tree at harvest was linearly dependent on leaf area per fruit (Palmer et al., 1991). Treatments caused no overall effects on shoot growth or leaf area per side of canopy. Those sides of trees without fruit had greater leaf area and shoot growth than did sides bearing fruit (Palmer et al., 1991). Webb et al. (1980) found that the mean fruit weight of 'Golden Delicious' was not affected by fruit number per spur or fruit number per branch. They concluded that as a determinant of fruit size, fruit number should be considered on a whole tree basis. Hansen (1977) also reported that mean fruit size was not influenced by the number of fruit per spur. Trees with a heavy crop load have fruit that is more dense than those with a lighter crop load. Fruit density, resulting from differences in intercellular air space, was greater in small than large fruits. Small fruits usually contain fewer and smaller cells than large fruits (Westwood et al., 1966). The rootstock has a major effect on crop load. Apple rootstock genotypes produce large differences in tree size, precocity, yield, and yield efficiency (Elfving and McKibbon, 1991; NC-140 Cooperators, 1996).

\section{REFERENCES}

Aldrich, W. W.-Fletcher, L. A. (1932): Relation of foliage system and fruit thinning to biennial bearing in apple. J. Amer. Soc. Hort. Sci. 29. 56-61.

Assaf, R.-Levin, I.-Bravdo, B. (1982): Apple fruit growth as a measure of irrigation control. Hort Science, 17. 59-61.

Batjer, L. P. (1965): Fruit thinning with chemicals. U.S.D.A. Agr. Info. Bul. 289. 1-27.

Batjer, L. P.-Billingsley, H. D.-Westwood, M. N.-Rogers, B. L. (1957): Predicting harvest size of apples at different times during the growing season. Proc. Amer. Soc. Hort. Sci. 70. 4657.

Batjer, L. P.-Thomson, B. J. (1961): Effect of 1-N. Methylcarbamate (Sevin) on thinning apples. Proc. Amer. Hort. Sci. 75. 1-4.

Batjer, L. P.-Westwood, M. N. (1960): 1-Napthyl N. Methylcarbamate, a new chemical for thinning apples. Proc. Amer. Soc. Hort. Sci. 27. 1-8.

Benson, N. R.-Bullock, R. M.-Chmelir, I. C.-Degman, E. S. (1957): Effects of levels of nitrogen and pruning on 'Starking' and 'Golden Delicious' apples. Proc. Amer. Soc. Hort. Sci. 70. 27-39.

Bergh, O. (1992): Cumulative effect of time of hand thinning on fruit size of 'Golden Delicious' and 'Granny Smith' apples. S. Afr. J. Plant and Soil Sci. 9. 2. 64-67.

Boynton, D.-Anderson, L. C. (1956): Some effects of mulching, nitrogen fertilization, and liming on 'McIntosh' apple trees, and the soil under them. Proc. Amer. Soc. Hort. Sci. 67. 2636.

Boynton, D.-Oberly, G. H. (1966): Apple nutrition. In: Childers, N. F. (ed.): Nutrition of fruit crops. Hort. Publ., Rutgers Univ., New Brunswick, NJ. 1-50.

Byers, R. E. (1999): Factors affecting return bloom in apples. The Mountaineer Grower, 556. 4-12.

Byers, R. E.-Barden, J. A.-Polomski, R. F.-Young, R. W.Carbaugh, D. H. (1990): Apple thinning by photosynthetic inhibition. J. Amer. Soc. Hort. Sci. 115. 1. 14-19. 46.

Chandler, W. H. (1937): Zinc as a nutrient for plants. Bot. Gaz. SCVIII. 4. 625-646.

Davidson, R. M. (1971): Effect of early season sprays of trace elements on fruit setting of apples. N.Z. J. Agr. Res. 14. 931935.

Dennis, F. G. Jr.-Neilson, J. C. (1999): Physiological factors affecting biennial bearing in tree fruit: The role of seeds in apple. Hort Technology, 9. 3. 317-322.

Elfving, D. C.-McKibbon, E. D. (1991): Effects of rootstock on productivity and pruning requirements of 'Starkspur Supreme Delicious' apple trees in the NC-140 cooperative planting. Fruit Var. J. 45. 242-246.

Erf, J. A.-Proctor, J. T. A. (1987): Changes in apple leaf water status and vegetative growth as influenced by crop load. J. Amer. Soc. Hort. Sci. 112. 617-620.

Fallahi, E. (1997a): Applications of endothallic acid, pelargoric acid, and hydrogen cyanamide for blossom thinning in apple and peach. Hort Technology, 7. 4. 18-22.

Fallahi, E. (1997b): Preharvest nitrogen optimization for maximizing yield and postharvest fruit quality of apples. Acta Hort. 448. 415-419.

Fallahi, E.-Williams, M. W.-Colt, W. M. (1997): Blossom thinning of 'Law Rome Beauty' apple with hydrogen cyanamide and monocarbamide dihydrogensulfate. J. Tree Fruit Prod. 2. 1. 33-44.

Ferguson, I. B.-Triggs, C. M. (1990): Sampling factors affecting the use of mineral analysis of apple fruit for the prediction of bitter pit. N.Z. J. Crop. Hort. Sci. 18. 147-152.

Ferguson, I. B.-Watkins, C. B. (1989): Bitter pit in apple fruit. Hort. Rev. 11. 289-355.

Fisher, E. G.-Walker, D. R.-Boynton, D.-Kwong, S. S. (1958): Studies on the control of magnesium deficiency and its effects on apple trees. Proc. Amer. Soc. Hort. Sci. 71. 1-10.

Forshey, C. G. (1976): Factors affecting the chemical thinning of 
apples. New York’s Food and Life Sciences Bul. 64. 1-14.

Forshey, C. G.-Elfving, D. C. (1977): Fruit numbers, fruit size, and yield relationships in 'McIntosh' apples. J. Amer. Soc. Hort. Sci. 102. 4. 399-402.

Forshey, C. G.-Elfving, D. C. (1989): The relationship between vegetative growth and fruiting in apple trees. Hort. Rev. 11. 229-287.

Francesconi, A. H.-Lakso, A. N.-Nyrop, J. P.-Barnard, J.-Denning, S. S. (1996): Carbon balance as a physiological basis for the interactions of European red mite and crop load on 'Starkrimson Delicious' apple trees. J. Amer. Soc. Hort. Sci. 121. 5. 959-966.

Greenham, D. W. P.-White, G. C. (1959): Control of magnesium deficiency in dwarf pyramid apples. J. Hort. Sci. 71. 1-10.

Hansen, P. (1977): The relative importance of fruits and leaves for the cultivar-specific growth rate of apple fruits. J. Hort. Sci. 52. 501-508.

Hansen, P. (1981): Boron toxicity and bud development in apple trees. Danish J. Plant Soil Sci. 85. 405-410.

Harley, H. H.-Moon, R. L. O. (1957): Effects of the additive Tween 20 and relatively low temperatures on apple thinning by naphthalene acetic acid sprays. Proc. Amer. Soc. Hort. Sci. 69. 21-27.

Johnson, D. S. (1994): Influence of time of flower and fruit thinning on the firmness of 'Cox's Orange Pippin' apples at harvest after storage. J. Hort. Sci. 69. 2. 197-203.

Jones, K. M.-Bound, S. A.-Koen, T. B.-Oakford, M. J. (1992): Effect of timing of hand thinning on the cropping potential of 'Red Fuji' apple trees. Aust. J. of Ex. Agr. 32. 417-420.

Jones, K. M.-Jotic, P.-Koen, T. B.-Longley, S. B.-Adams, G. (1988a): Restructuring and cropping large 'Red Delicious' apple trees with paclobutrazol and diaminozide. J. Hort. Sci. 63. 19-25.

Jones, K. M.-Koen, T. B. (1986): Manipulation of blossom density and the effects of ethephon thinning of 'Golden Delicious'. Acta Horticulture, 179. 653-657.

Jones, K. M.-Koen, T. B.-Longley, S. B.-Oakford, M. J. (1988b): Thinning 'Golden Delicious' apples with naphthalene acetic acid in relation to spray concentration, volume and time of day. J. Hort. Sci. 63. 27-30.

Jones, K. M.-Koen, T. B.-Meredith, R. J. (1984): Thinning 'Golden Delicious' apples with naphthalene acetic acid in relation to spray concentration, volume, and time of day. J. Hort. Sci. 59. 27-30.

Jones, K. M.-Koen, T. B.-Oakford, M. J.-Bound, S. A. (1989): Thinning 'Red Fuji' apples with ethephon and NAA. J. Hort. Sci. 64. 524-532.

Koen, T. B.-Jones, K. M. (1985): A model of ethephon thinning of 'Golden Delicious' apples. J. Hort. Sci. 60. 13-19.

Koen, T. B.-Jones, K. M.-Longley, S. B. (1988): Spray thinning strategies for 'Red Delicious' apple using naphthalene acetic acid and ethephon. J. Hort. Sci. 63. 31-35.

Lakso, A. N.-Robinson, T. L.-Goffinet, M. C. (1996): Influence of Fruit Competition on Size, and the Importance of Early Thinning. New York Fruit Quart. 4. 1. 7-9.

Lee, B.-Priestly, J. H. (1924): The plant cuticle. I. Its structure, distribution and function. Annual Botany, 38. 525-545.

Leopold, A. C.-Kriedemann, P. E. (1975): Plant growth and development. 2nd Ed. McGrall-Hill Inc. New York, 320.

Luckwill, L. C. (1970): The control of growth and fruitfulness of apple trees. In: Luckwill, L. C.-Cutting, C. V. (eds.): Physiology of tree crops. Academic Press, London, 237-254.

Luckwill, L. C.-Weaver, P.-MacMillan, J. (1969): Gibberellins and other growth hormones in apple seeds. J. Hort. Sci. 44. 413424.

Maggs, D. H. (1963): The reduction and growth of apple trees brought about by fruiting. J. Hort. Sci. 38. 119-128.

Magness, J. R.-Batjer, L. P.-Regeimbal, L. O. (1948): Apple tree response to nitrogen applied at different season. J. Amer. Res. 76. 1-25.

McArtney, S.-Palmer, J. W.-Adams, H. M. (1996): Crop loading studies with 'Royal Gala' and 'Braeburn' apples: effect of time and level of hand thinning. N.Z. J. of Crop and Hort. Sci. 24. 401-407.

McDaniels, L. H.-Heinicke, A. J. (1930): Factors affecting apple fruit set. Cornell Bull. 407.

Neilsen, G. H. (1994): Phosphorus on replanted orchards. In: Peterson, A. B.-Stevens, R. G. (eds.): Tree fruit nutrition. Goodfruit Grower, Yakima, Wash., 71-77.

Neilson, G. H. (1988): Seasonal variation in leaf zinc concentration of apples receiving dormant zinc. Hort Science, 23. 1. 130-132.

Neilson, G. H.-Hogue, E. J.-Parchomchuk, P. (1990): Flowering of apple tree in the second year is increased by first-year phosphorus fertilization. Hort Science, 25. 10. 1247-1250.

Palmer, J. W. (1992): Effects of varying crop load on photosynthesis, dry matter production and partitioning of 'Crispin'/M.27 apple trees. Tree Physiology, 11. 19-33.

Palmer, J. W.-Adams, H. M. (1996): Crop loading studies with 'Royal Gala' and 'Braeburn' apples: effect of time and level of hand thinning. N.Z. Journal of Crop and Hort. Sci. 24. 401407.

Palmer, J. W.-Cai, Y. L.-Edjama, Y. (1991): Effect of part-tree flower thinning on fruiting, vegetative growth, and leaf photosynthesis in 'Cox's Orange Pippin' apple. J. Hort. Sci. 66. 3. 319-325.

Potter, G. F. (1936): Biennial bearing of 'McIntosh'. J. Amer. Soc. Hort. Sci. 34. 139-141.

Preston, A. P.-Quinlan, J. D. (1968): A fruit thinning experiment with ‘Cox’s Orange Pippin' apple. Rep. E. Malling Res. Stn. for 1967. 75-78.

Quinlan, J. D.-Preston, A. P. (1968): Effects of thinning blossom and fruitlets on growth and cropping of sunset apple. J. Hort. Sci. 43. 373-381.

Robinson, T.-Lakso, A.-Stover, E.-Hoying, S. (1998): Practical thinning programs for New York. New York Fruit Quart. 6. 1. 14-18.

Rogers, B. L.-Thompson, A. H. (1962): Yield, fruit size and growth of 'York Imperial' apple trees as affected by chemical thinning and differential nitrogen nutrition for 6 years. Proc. Amer. Soc. Hort. Sci. 80. 50-57.

Rogers, B. L.-Thompson, A. H. (1969): Chemical thinning of apple trees using concentrate sprays. J. Amer. Soc. Hort. Sci. 94. 24-25.

Southwick, F. W.-Weeks, W. D. (1949): Chemical thinning apples at blossom time and up to four weeks from petal fall. J. Amer. Soc. Hort. Sci. 53. 143-147.

Stebbins, B. (1989): Maturity of new apple varieties. The Goodfruit Grower, 40. 7-9.

Stiles, W. C. (1980): Pruning, growth regulator, and nutrition studies with apples. Annu. Rpt. Maine State Pomol. Soc. 2534.

Stiles, W. C. (1998): Orchard nutrition research. New York Fruit Quart. 6. 2. 8-10.

Stiles, W. C. (1999): Effects of nutritional factors on regular cropping of apple. Hort Technology, 9. 3. 328-331. 
Stiles, W. C.-Reid, W. S. (1991): Orchard nutrition management. Cornell Univ. Coop. Ext. Info. Bul. 219.

Stouffer, R. F.-Green, G. M.-Ritter, C. M.-Barrat, J. G. (1978): 'Nittany' apple. Hort Science, 13. 3. 306-306.

Tami, M.-Lombard, P. B.-Righetti, T. L. (1986): Effect of urea nitrogen on fruitfulness and fruit quality of 'Starkspur Golden Delicious' apple trees. J. Plant Nutr. 9. 1. 75-85.

Tukey, R. B. (1970): Predicting the harvest size of 'Bartlett' pear. Wash. State Univ. Ext. Pub. E.M 3403. 1-7.

Voltz, R. K.-Ferguson, I. B.-Bowen, J. H.-Watkins, C. B. (1993): Crop load effects on fruit mineral nutrition, maturity, fruiting and tree growth of 'Cox's Orange Pippin' apple. J. Hort. Sci. 68. 1. 127-137.

Way, D. W. (1965): Carbaryl as a fruit thinning agent. II Condition and time of application. J. Hort. Sci. 42. 355-365.

Webb, R. A.-Purves, J. V.-Beech, M. G. (1980): Size factors in apple fruit. Scientia Horticulturae, 13. 205-212.

Weinbaum, S. A.-Simons, R. K. (1976): Seed number and fruit set in apple. Fruit Var. J. 30. 3. 82-84.

Westwood, M. N.-Batjer, L. P. (1960): Effects of environment and chemical additives on absorption of napthalene acetic acid by apple leaves. Proc. Amer. Soc. Hort. Sci. 76. 16-29.

Westwood, M. N.-Batjer, L. P.-Billingsley, H. D. (1966): Cell size, cell number, and fruit density of apples as related to fruit size, position in cluster, and thinning method. J. Amer. Soc Hort.
Sci. 91. 51-62.

Williams, K. M. (1999): Growth regulator programs for chemical thinning of apple. In: Crop protection guide for tree fruits in Washington. Wash. St. Univ. Ext. Publ. EB 0419. 68-79.

Williams, K. M.-Fallahi, E. (1999): The effects of exogenous bioregulators and environment on regular cropping of apple. Hort Technology, 9. 3. 323-327.

Williams, M. W. (1994): New chemical approaches for control of biennial bearing of apples. In: Hedin, P. A. (ed.): Bioregulators for crop protection and pest control. Amer. Chem. Soc. Symp. Ser. 557. 205th Annv. Meeting, Denver, CO. 16-25.

Williams, M. W.-Edgerton, L. J. (1981): Fruit thinning of apples and pears with chemicals. U.S. Dept. Agr. Info. Bul. 289.

Williams, R. R. (1965): The effect of summer nitrogen applications on the quality of apple blossom. J. Hort. Sci. 40 . 31-41.

Woodbridge, C. G.-Venegas, A.-Crandall, P. C. (1971): The boron content of developing pear, apple. J. Hort. Sci. 48. 114-118.

NC-140 Cooperators (1996): Rootstock and scion cultivars interact to affect apple tree performance: a five-year summary of the 1990 NC-140 cultivar/rootstock trial. Fruit Var. J. 50. 3. 175187.

U.S.D.A. Soil Conservation Service (1960): Soil Survey Series. 30. 105-106. 